\title{
INCREASING ANTIOXIDANT CONTENT OF BROCCOLI SPROUTS USING ESSENTIAL OILS DURING COLD STORAGE
}

\author{
AML A. EL-AWADY*1, WESAM I. A. SABER ${ }^{2}$, NABIL M. ABDEL HAMID ${ }^{3}$ \\ AND HANAA A. HASSAN ${ }^{4}$
}

${ }^{1}$ Department of Vegetable Postharvest and Handling Research, Horticulture Research Institute, Agricultural Research Center, Giza, Egypt

${ }^{2}$ Microbial Activity Unit, Microbiology Department, Soils, Water and Environment Research Institute, Agricultural Research Center, Giza, Egypt

${ }^{3}$ Biochemistry Department, Pharmacy College, Kafrelsheikh University, Egypt

${ }^{4}$ Department of Zoology, Division of Physiology, Faculty of Science, Mansoura University, Mansoura, Egypt

\begin{abstract}
AML A. EL-AWADY - WESAMI I.A. SABER - NABIL M. ABDEL HAMID - HANAA A. HASSAN: Increasing antioxidant content of broccoli sprouts using essential oils during cold storage. Agriculture (Polnohospodárstvo), vol. 62, 2016, no. 3, pp. $111-126$.
\end{abstract}

Broccoli sprouts are natural functional foods for cancer prevention because of their high content of glucosinolate and antioxidant. Sprouts and mature broccoli are of potential importance in devising chemoprotective strategies in humans. The aim of the investigation was to study the effect of essential oils on broccoli seed germination, increase their antioxidant content and determine the glucosinolate concentration and other phytochemical parameters in 3-day -old sprouts during cold storage at $4{ }^{\circ} \mathrm{C}$ and $95 \% \mathrm{RH}$ for 15 days. The results showed that all treatments of essential oils increased germination index, seed germination percentage, seedling length, seedling vigour index, yield and the antioxidant content of broccoli sprout and reduced the microbial load compared to the control. Fortunately, the coliform bacteria was not detected in all treatments. Different essential oils of fennel, caraway, basil, thyme and sage were tested. The thyme oil was the best treatment, which increased the accumulation of the phenolic compounds and glucosinolate compared to the control at different storage periods. In the sprouts treated with thyme oil treatment and the control, at the end of cold storage, $1.98 \%$ and $28.06 \%$ of total phenolic content, $1.90 \%$ and $20.28 \%$ of 2,2 -diphenyl1-picrylhydrazyl (DPPH) radical scavenging capacity, $1.39 \%$ and $58.33 \%$ of flavonoids, $1.93 \%$ and $36.25 \%$ of vitamin C, $2.95 \%$ and $22.02 \%$ of anthocyanin and $2.18 \%$ and $49.12 \%$ of glucosinolate were lost, respectively. A slight reduction differences in all detected compound concentrations occurred between the initial content and the end of storage period because of the application of thyme oil compared to the control. Therefore, the total glucosinolate level in the sprout $(27.02 \mu \mathrm{g} / \mathrm{g}$ F.W. $)$ was higher than that in the florets $(7.37 \mu \mathrm{g} / \mathrm{g}$ F.W. $)$. Glucoraphanin was the most abundant aliphatic glucosinolate present in the sprout and reached the highest value $(16.24 \mu \mathrm{g} / \mathrm{g} \mathrm{F}$.W.) followed by glucoerucin $(5.9 \mu \mathrm{g} / \mathrm{g}$ F.W.) and glucoiberm(1.2 $\mu \mathrm{g} / \mathrm{g}$ F.W. $)$.

Key words: broccoli, sprout, antioxidant, polyphonic compounds, flavonoids, essential oils

Broccoli sprouts are considered as a functional food. Essential nutrient content provides diverse secondary metabolites and phytochemicals (Villarreal
-García et al. 2016). The phenolic compounds, especially flavonoids and anthocyanin, show a great ability to capture free radical that lead to oxidative

Aml A. El-Awady, PhD. (*Corresponding author), Department of Vegetable Postharvest and Handling Research, Horticulture Research Institute, Agricultural Research Center, Giza 12619, Egypt. E-mail: aml.elawady@yahoo. com

Wesam I. A. Saber, Microbial Activity Unit, Microbiology Department, Soils, Water and Environment Research Institute, Agricultural Research Center, Giza 12619, Egypt. E-mail: wiasaber@gmail.com

Nabil M. Abdel-Hamid, Biochemistry Department, Pharmacy College, Kafrelsheikh University, Kafrelsheikh 33516, Egypt. E-mail: nabilmohie@yahoo.com

Hanaa A. Hassan, Department of Zoology, Division of Physiology, Faculty of Science, Mansoura University, Mansoura 35516, Egypt. E-mail: drhanaahassan@yahoo.com 
stress; therefore, these compounds are attributed a beneficial effect in the prevention of cardiovascular diseases, circulatory problems, neurological disorders and cancer (Baenas et al. 2014). Broccoli has been identified as a vegetable with potential anticancer activity because of high levels of glucosinolates that are divided into three major categories: aliphatic, indole and aromatic glucosinolates (Yan \& Chen 2007). The high content of the aliphatic glucosinolates in broccoli sprouts is mainly attributed to glucoraphanin. The degradation products of aliphatic glucosinolates are considered to have the higher phase 2 detoxification enzyme inducer ability than the other two groups, which is effective in blocking chemical carcinogenesis; therefore, they are thought to be the main contributor to the protection against carcinogenesis. The glucoraphanin can be hydrolysed tosulphoraphane (Figure 1). Sulphoraphane is a naturally occurring isothiocyanate in cruciferous vegetables and has a high capacity to induce phase 2 enzymes (López-Cervantes et al. 2013). This compound plays an important role in controlling, preventing or blocking any of the multiple stages of the carcinogenic process (Parnaud et al. 2004). Moreover, broccoli sprouts have 20-50 times higher concentration of glucoraphaninand 30-50 times higher concentration of sulphoraphane when compared to mature plants. Level of myrosinaseenzyme, which protects against carcinogens, in broccoli sprouts is 10-100 times higher than that in mature broccoli
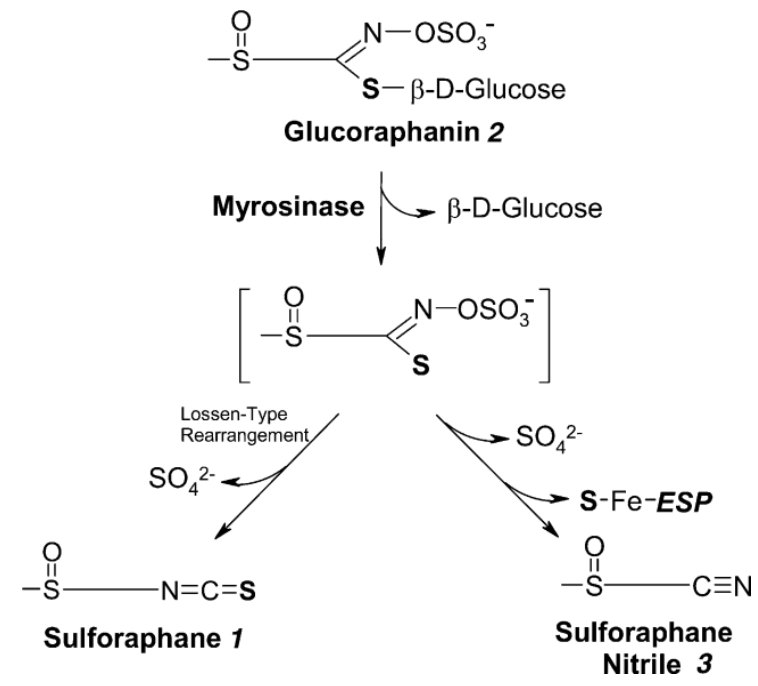

Figure 1. Formation mechanism of sulphoraphane and sulphoraphane nitrile in broccoli sprouts (Matusheski et al. 2004) heads (Fahey et al. 1997). Use of sprouts in the daily nutrition maintains the nutritional value, protects from diseases and eliminates spoilage and pathogenic bacteria.

The use of treatments with essential oil rich in antioxidant to stimulate broccoli seed germination should be considered. Application of $4 \%$ thyme and basil oils reduced the pathogenic fungi from seed to seedling and had a positive effect on the seed germination of infected seeds (Nguefack et al. 2005). Aromatic plants, especially essential oils, are well known for their antioxidant and antimicrobial properties that prevent food degradation and alteration (Justesen \& Knuthsen 2001), as they are rich in phenolic substances, usually referred to as polyphenols, which are ubiquitous components of plants and herbs.

Campas-Baypoli et al. (2010) indicate that $30 \mathrm{~g}$ of broccoli sprouts may have the amount of antioxidant present in $600 \mathrm{~g}$ of mature broccoli. Furthermore, broccoli sprouts are sold in sealed plastic containers and destined to be stored in domestic refrigerators for consumption. Although the concentration of bioactive compounds may be high at the time of harvest, there is no accurate data that document the stability of these phytochemicals during the storage (West et al. 2004). Several researches have shown that the temperature and storage time are the main factors responsible for the changes in the concentration of diverse compounds, such as glucosinolates (Fiskaa et al. 2009). Therefore, it is necessary to know the stability of glucosinolates in the food matrix under refrigeration storage.

The aim of this investigation was to use the essential oils during cold storage to produce healthy broccoli sprout with high nutritive values, quality and antioxidants content with low microbial load. After choosing the best oil treatment, the glucosinolate concentration, total phenolic content, flavonoids, vitamin $\mathrm{C}$ and $\mathrm{DPPH}$ radical scavenging capacity content in sprouts were determined during cold storage.

\section{MATERIAL AND METHODS}

\section{Plant material and germination condition}

The study was conducted in the Laboratory of Mansoura Horticultural Research Station, Horti- 
culture Research Institute, Egypt, during the period from 2012 to 2014 seasons. Broccoli seeds (Brassica oleracea $\mathrm{L}$. var. italica and the variety name is F1 Hybrid Sakura) from Tokita Seeds CO., LTD (Saitama, Japan) was used. Germination of broccoli seeds was carried out according to Pérez-Balibrea et al. (2011). The seeds ( 1,000 seeds, nearly $5 \mathrm{~g}$ ) for each treatment were soaked in $0.5 \% \mathrm{v} / \mathrm{v}$ sodium hypochlorite solution for $15 \mathrm{~min}$, then immersed in $50 \mathrm{ml}$ of distilled water for $5 \frac{1}{2}$ hours with shaking for every $30 \mathrm{~min}$ and washed with distilled and sterilised water. On September 15, the seeds were sown broadcast over absorbent medical cotton in sprouting plastic containers $(220 \mathrm{~mm} \times 110 \mathrm{~mm})$. The cotton was treated with emulsion of different natural essential oils at $0.05 \%$ concentration and emulsified using $1.5 \mathrm{ml} / 1$ of Tween 80 , and the containers were closed immediately. Germination conditions were maintained at $25 \pm 2^{\circ} \mathrm{C}$ with a cycle of $16 \mathrm{~h}$ light and $8 \mathrm{~h}$ darkness, a relative humidity $(\mathrm{RH})$ between $80 \%$ and $90 \%$ and light intensity of $7.4 \mathrm{lmol} / \mathrm{m}^{2} / \mathrm{s}$. After 3 days, sprouts were cut from their root mats, and $20 \mathrm{~g}$ of sprouts from each was weighed and placed in a container. The container was stored and placed at $4^{\circ} \mathrm{C}$ and $95 \% \mathrm{RH}$ in the dark simulating a domestic refrigerator for 15 days for the best treatment and control.

\section{Characterisation of essential oils}

The major compounds of essential oil of caraway, Carum carvi, were carvone (57\%) and limonene $(30 \%)$. The other compounds were oleic acid (C 18:1), which accounted for 52.28\%, and linoleic acid (C 18:2), which accounted for 30.84\%. Carum carvi essential oil was characterised by the predominance of oxygenated monoterpenes $(79.79 \%)$. In essential oil of fennel, Foeniculum vulgare, the most abundant component was trans-anethole $(83.80 \%)$, then limonene $(9.34 \%)$, fenchone $(4.84 \%)$ and methyl chavicol $(1.36 \%)$. The other compounds were monoterpenes (15.04\%) and phenylpropanoids $(84.79 \%)$. According to the results of the chemical analysis of thyme essential oil, Thymus vulgaris, 25 compounds were identified, which represented $94.53 \%$ of the oil content. The highest percentage of compounds includes three classes: monoterpene hydrocarbons, aromatic hydrocarbons and oxidised monoterpenes. More than half of the total com- pounds of thyme essential oil include six dominant compounds. Amongst them, the most dominant is the oxidised monoterpene thymol $40.12 \%$ and the monoterpene hydrocarbon p-cymene $(21.15 \%)$. Other dominant components of this essential oil are the following: carvacrol (14.34\%) and linalool $(4.54 \%)$. The major constituents detected in our samples of basil, Ocimum basilicum, include eugenol (39.51\%), linalool (27.24\%), 1,8 cineole (17.88\%) and ß-bisabolene (15.37\%). The dominant constituent in essential oils of sage, Salvia officinalis, is thujone (41.33\%). 1,8 cineole is also present in high amount (39.5\%).

\section{Essential oils extraction methods}

Seeds of fennel, caraway and herbs of basil, thyme and sage ( $200 \mathrm{~g}$ from each one) were used for oil extraction by hydro-distillation for $2-3 \mathrm{~h}$ according to Charles and Simon (1990). After extraction, essential oils were separated and their basic constituents were identified using gas liquid chromatography (GLC).

\section{Experimental design for essential oils treatments}

A completely randomised design with three replicates was used. The experiment included seven treatments of the above-mentioned essential oils in addition to hot water $\left(36^{\circ} \mathrm{C}\right)$ treatment and tap water as a positive control.

Mature winter grown broccoli was sown on 18 November in both seasons and was harvested by hand on 28 January from the field of the Baramoon Experimental Farm. The variety used was the same as mentioned previously. The other agricultural practices were carried out as commonly followed in the district. Broccoli was harvested when the diameter of floret was about $0.35-0.40 \mathrm{~cm}$. On 26 January, the germination of broccoli seeds has been done in incubator chamber at $20^{\circ} \mathrm{C}$ and $60 \% \mathrm{RH}$ for 3 days. After germination, the samples of sprout were taken for chemical analysis to compare with samples of florets.

\section{Recorded data}

\section{Vegetative characters of broccoli sprout}

Germination [\%] = Total number of normal seedlings / Total number of seeds 
Germination index (GI) was calculated according to the following formula:

$$
\mathrm{GI}=\Sigma \mathrm{T}_{\mathrm{i}} \times \mathrm{N}_{\mathrm{i}} / \mathrm{S}
$$

where: $T_{i}$ is the number of days after planting, $N_{i}$ is the number of seeds germinated on day I and $\mathrm{S}$ is the total number of planted seeds.

Seedling vigour index $=$ Germination $[\%] \times$ Seedling length $[\mathrm{cm}]$

Germination index and seedling vigour index were calculated by the above equation of International Seed Testing Association (2010). At the end of germination (3 days), 10 seedlings from each treatment were taken randomly for the determination of sprout length $[\mathrm{cm}]$ and fresh weight of sprout [g].

\section{Methanolic extracts for phytochemical determina- tion}

Extraction was performed under dark conditions using the solvent methanol/water at a ratio $8: 2$; specifically weighed $0.3 \mathrm{~g}$ of fresh broccoli sprouts were added to $5 \mathrm{ml}$ of $80 \% \mathrm{v} / \mathrm{v}$ methanol, homogenised for $30 \mathrm{~s}$, vortexed and sonicated for $5 \mathrm{~min}$. The mixture was filtered using Whatman no. 41 paper (Du et al. 2009).

Total phenolic and total flavonoid contents measurements

Total phenolic content was determined using the Folin-Ciocalteu method. In an Eppendorf tube, $7.9 \mathrm{ml}$ of distilled water, $100 \mu \mathrm{l}$ of broccoli sprout extract and $500 \mu 1$ of Folin-Ciocalteu reagent (1:1 with water) were added and mixed. Exactly after $1 \mathrm{~min}, 1,500 \mu \mathrm{l}$ of sodium carbonate $(20 \mathrm{~g} / 100 \mathrm{ml})$ was added and the mixture was mixed and allowed to stand at room temperature in the dark for $2 \mathrm{~h}$. The absorbance was read at $765 \mathrm{~nm}$ by spectrophotometer. Gallic acid was used for calibration curve. Results were expressed as mg GAE/100 g F.W. (Du et al. 2009).

In order to determine the total flavonoid content, $150 \mu \mathrm{l}$ of broccoli sprout extract, $1,700 \mu \mathrm{l}$ of $30 \%$ ethanol, $150 \mu \mathrm{l}$ of $0.5 \mathrm{~mol} / 1 \mathrm{NaNO}_{2}$ and $150 \mu \mathrm{l}$ of $0.3 \mathrm{~mol} / 1 \mathrm{AlCl}_{3} \cdot 6 \mathrm{H}_{2} \mathrm{O}$ were added and mixed. After $5 \mathrm{~min}, 1 \mathrm{ml}$ of $1 \mathrm{~mol} / 1 \mathrm{NaOH}$ was added, and the mixture was measured spectrophotometrically at $506 \mathrm{~nm}$. Results were expressed as mg/100 g F.W. of flavonoids content in sprouts (Du et al. 2009).

\section{Vitamin $C$ and Anthocyanin}

Vitamin $\mathrm{C}$ was determined by titration of fruit juices with indophenol method and indicated as $\mathrm{mg}$ ascorbic acid per $100 \mathrm{ml}$ (AOAC 2000).

Total anthocyanin content was measured using a spectrophotometric differential $\mathrm{pH}$ method following the procedure of Yuan et al. (2010). Frozen samples $(100 \mathrm{mg})$ were crushed into powder and extracted separately with $2 \mathrm{ml}$ of $\mathrm{pH} 1.0$ buffer containing $50 \mathrm{mM} \mathrm{KCl}$ and $150 \mathrm{mM} \mathrm{HCl}$ as well as $2 \mathrm{ml}$ of $\mathrm{pH} 4.5$ buffer containing $400 \mathrm{mM}$ sodium acetate and $240 \mathrm{mM} \mathrm{HCl}$. The mixtures were centrifuged at $12,000 \mathrm{~g}$ for $15 \mathrm{~min}$ at $4^{\circ} \mathrm{C}$. Supernatants were collected and diluted for direct measurement of absorbance at $510 \mathrm{~nm}$. Total anthocyanin content was calculated using the following equation:

Amount $(\mathrm{mg} / \mathrm{g} \mathrm{F.W})=.\left(\mathrm{A}_{510 \mathrm{~nm}}\right.$ at $\mathrm{pH} 1.0-\mathrm{A}_{510 \mathrm{~nm}}$ at $\mathrm{pH} 4.5) \times 484.8 / 24.825 \times$ Dilution factor

The molecular mass of cyanidin-3-glucosidechloride is 484.8 and its molar absorptivity (e) at $510 \mathrm{~nm}$ is 24.825 . Each sample was analysed in triplicate, and the results were expressed as the average of \pm SD.

\section{Total chlorophyll}

Total chlorophyll content of broccoli was determined by using a spectrophotometry (Sabir \& Agar 2011). One gram of blended broccoli portions was homogenised with $10 \mathrm{ml}$ of chloroform-methanol mixture $(2: 1 \mathrm{v} / \mathrm{v})$ for $1 \mathrm{~min}$. Extracts was filtered with filter paper. The residue was resuspended in $10 \mathrm{ml}$ of chloroform-methanol mixture and then filtered. All the filtrates were combined and solutions were supplemented with chloroform-methanol mixture to $25 \mathrm{ml}$ final volume. Total chlorophyll was determined by measuring absorbance of the solution in UV spectrophotometer at 663 and $645 \mathrm{~nm}$ against chloroform-methanol blank. The total chlorophyll was estimated by the following formula:

$$
\text { Total chlorophyll }[(\mathrm{mg} \mathrm{100/g})]=8.02 \times(\mathrm{A} 663)+
$$$$
20.02 \times(\text { A } 645)
$$

\section{Measurement of DPPH radical scavenging capacity}

2-Diphenyl-1-picrylhydrazyl (DPPH) radical scavenging capacity was determined by BrandWilliams et al. (1995). A working solution of 0.1 mM DPPH radical was prepared in $80 \%$ methanol, 
which shows an absorbance of 1.237 at $515 \mathrm{~nm}$. The DPPH radical scavenging capacity of the sample was expressed as $\mathrm{mM}$ Trolox equivalent (TE) per 100 g F.W.

\section{Extraction and Desulphation of Glucosinolates}

Desulphoglucosinolate contents were determined according to Kiddle et al. (2001). Each sample $(20 \mu 1)$ was analysed on a Merck-Hitachi HPLC system (Merck-Hitachi Ltd., Tokyo, Japan) consisting of a variable UV detector set at $227 \mathrm{~nm}$ and a Lichosphere RP-18 column (Merck, Darmstdat, Germany) $(\mathrm{RP} 18,25 \mathrm{~cm} \times 0.4 \mathrm{~cm}, 5 \mu \mathrm{m}$ particle size $)$. The mobile phase was a mixture of water (A) and acetonitrile (B). Desulphoglucosinolates were eluted off the column in 28 min with a linear gradient starting with $1 \% \mathrm{~B}$ and reaching $20 \% \mathrm{~B}$ at $28 \mathrm{~min}$ and $90 \% \mathrm{~B}$ at $30 \mathrm{~min}$. The flow rate was $1.5 \mathrm{ml} / \mathrm{min}$. Extraction and desulphation were done according to Vallejo et al. (2002).

\section{Microbial evaluation in the stored broccoli sprouts}

The pour plate method was used for the enumeration of the microbial community in broccoli sprouts through the 15-day storage period, with 5 -day interval. The total bacterial, yeast and fungal counts were determined using the media of Collins and Lyne (1985) and Marshall (1992), after 2, 3 and 5 days of incubation at $30^{\circ} \mathrm{C}$. The enumeration of coliform bacteria was performed according to Lorenz et al. (1982). The counts of the different groups were expressed as colony forming unit (CFU) per gram of fresh sprouts.

\section{Statistical Analysis}

Data were analysed using analysis of variance technique, and the differences between individual pairs of treatment means were compared using Duncan's multiple range test at 5\% according to Snedecor and Cochran (1989).

\section{RESULTS}

\section{Vegetative characters of broccoli sprout}

The treatments with essential oil rich in antioxidant stimulates broccoli seed germination. All different essential oils had significant effects on germination index [\%], germination [\%], seedling length $[\mathrm{cm}]$, seedling vigour index and yield $[\mathrm{g}]$ compared with the control during the two seasons (Table 1). The fennel, caraway and thyme oils increased the seed germination index of the seeds by $171.43 \%, 170.29 \%$ and $148.02 \%$ (an average of the two seasons), respectively, compared with the control $(100 \%)$. The increases in seed germination percentage over the control (tap water) reached to $12.73 \%, 13.74 \%$ and $15.82 \%$ for the most effec-

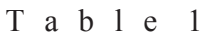

Vegetative characters of broccoli seeds treated with different essential oils before cold storage

\begin{tabular}{|c|c|c|c|c|c|c|c|c|c|c|c|}
\hline & \multirow[t]{2}{*}{ Treatment } & \multicolumn{2}{|c|}{$\begin{array}{c}\text { Germination } \\
\text { index } \\
{[\%]} \\
\end{array}$} & \multicolumn{2}{|c|}{$\begin{array}{c}\text { Seed germination } \\
{[\%]}\end{array}$} & \multicolumn{2}{|c|}{$\begin{array}{l}\text { Seedling length } \\
{[\mathrm{cm}]}\end{array}$} & \multicolumn{2}{|c|}{$\begin{array}{l}\text { Seedling vigour } \\
\text { index } \\
{[\mathrm{cm}]} \\
\end{array}$} & \multicolumn{2}{|c|}{$\begin{array}{l}\text { Yield [g] } \\
\text { container / } \\
242 \mathrm{~cm}^{2} \\
\end{array}$} \\
\hline & & 2012 & 2013 & 2012 & 2013 & 2012 & 2013 & 2012 & 2013 & 2012 & 2013 \\
\hline 1 & Water (control) & $13.36^{\mathrm{e}}$ & $12.96^{\mathrm{d}}$ & $86.67^{c}$ & $86.00^{\mathrm{a}}$ & $4.67^{c}$ & $4.00^{\mathrm{b}}$ & $4.03^{c}$ & $3.44^{\mathrm{c}}$ & $36.40^{\mathrm{e}}$ & $34.20^{\mathrm{d}}$ \\
\hline 2 & Hot water & $14.61^{\mathrm{de}}$ & $13.02^{\mathrm{d}}$ & $93.78^{b}$ & $90.44^{\mathrm{bc}}$ & $5.00^{\mathrm{c}}$ & $4.80^{\mathrm{b}}$ & $4.71^{\mathrm{c}}$ & $4.33^{c}$ & $40.88^{\text {de }}$ & $37.21^{\mathrm{d}}$ \\
\hline 3 & Fennel oil & $22.01^{\mathrm{a}}$ & $23.01^{\mathrm{a}}$ & $97.33^{\mathrm{ab}}$ & $97.33^{\mathrm{a}}$ & $7.33^{\mathrm{ab}}$ & $7.67^{\mathrm{a}}$ & $7.13^{\mathrm{ab}}$ & $7.47^{\mathrm{ab}}$ & $56.90^{\mathrm{b}}$ & $49.17^{\mathrm{c}}$ \\
\hline 4 & Caraway oil & $21.94^{\mathrm{a}}$ & $22.88^{\mathrm{a}}$ & $97.33^{\mathrm{ab}}$ & $99.00^{\mathrm{a}}$ & $8.00^{\mathrm{ab}}$ & $8.33^{\mathrm{a}}$ & $7.79^{\mathrm{a}}$ & $8.25^{\mathrm{a}}$ & $54.97^{\mathrm{bc}}$ & $67.75^{\mathrm{a}}$ \\
\hline 5 & Basil oil & $20.22^{\mathrm{ab}}$ & $21.82^{\mathrm{ab}}$ & $94.67^{b}$ & $92.33^{b}$ & $7.00^{\mathrm{b}}$ & $7.67^{\mathrm{a}}$ & $6.63^{\mathrm{b}}$ & $7.07^{\mathrm{b}}$ & $64.87^{\mathrm{a}}$ & $68.17^{\mathrm{a}}$ \\
\hline 6 & Thyme oil & $18.81^{\mathrm{bc}}$ & $20.14^{\mathrm{b}}$ & $100.00^{\mathrm{a}}$ & $100.00^{\mathrm{a}}$ & $8.20^{\mathrm{a}}$ & $8.30^{\mathrm{a}}$ & $8.20^{\mathrm{a}}$ & $8.30^{\mathrm{a}}$ & $66.54^{\mathrm{a}}$ & $67.75^{\mathrm{a}}$ \\
\hline 7 & Sage oil & $16.91^{\mathrm{cd}}$ & $17.76^{\mathrm{c}}$ & $100.00^{\mathrm{a}}$ & $100.00^{\mathrm{a}}$ & $7.83^{\mathrm{ab}}$ & $7.83^{\mathrm{a}}$ & $7.83^{\mathrm{a}}$ & $7.83^{\mathrm{ab}}$ & $47.83^{\mathrm{cd}}$ & $49.17^{\mathrm{c}}$ \\
\hline
\end{tabular}

Means followed by the same letter (s) within each column do not significantly differ using Duncan's multiple range test at the level of $5 \%$ 
tive treatments, respectively. Thyme, caraway and fennel oils had significant increases in the seedling vigour index and yield over the control to $50.25 \%$, $73.82 \%$ and $90.22 \%$, respectively (means of the two seasons).

\section{Phytochemical characters}

All treatments significantly surpassed over the control in broccoli sprout bio-constituents, that is, total phenolic acid, total flavonoid content, anthocyanin and ascorbic acid, whilst the control treatment gave the highest DPPH radical scavenging

$\mathrm{T}$ a b 1 e 2

Phytochemical screening by GLC for 3-day-old broccoli sprouts produced from seeds treated with essential oils before cold storage ( 0 time)

\begin{tabular}{|c|c|c|c|c|c|c|c|c|c|c|c|}
\hline & \multirow[t]{2}{*}{ Treatment } & \multicolumn{2}{|c|}{$\begin{array}{c}\text { Total phenolic } \\
\text { acid } \\
{[\mathrm{mg} / 100 \mathrm{~g} \mathrm{~F} . \mathrm{W} .]}\end{array}$} & \multicolumn{2}{|c|}{$\begin{array}{l}\text { Total flavonoids } \\
\text { [mg/100 g F.W.] }\end{array}$} & \multicolumn{2}{|c|}{$\begin{array}{c}\text { Anthocyanin } \\
\text { [mg/100 g F.W. }]\end{array}$} & \multicolumn{2}{|c|}{$\begin{array}{c}\text { Ascorbic acid } \\
{[\mathrm{mg} / 100 \mathrm{~g} \mathrm{~F} . \mathrm{W} .]}\end{array}$} & \multicolumn{2}{|c|}{$\begin{array}{c}\text { DPPH } \\
{[\mathrm{Mmol} \mathrm{TE} / \mathrm{g}} \\
\text { F.W. }]\end{array}$} \\
\hline & & 2012 & 2013 & 2012 & 2013 & 2012 & 2013 & 2012 & 2013 & 2012 & 2013 \\
\hline 1 & Water & $83.33^{\mathrm{d}}$ & $84.11^{\mathrm{e}}$ & $91.99^{d}$ & $95.18^{\mathrm{e}}$ & $7.13^{\mathrm{d}}$ & $7.70^{\mathrm{d}}$ & $70.58^{\mathrm{e}}$ & $81.23^{\mathrm{d}}$ & $23.66^{\mathrm{a}}$ & $24.66^{\mathrm{a}}$ \\
\hline 2 & Hot water & $88.71^{\mathrm{c}}$ & $88.56^{\mathrm{c}}$ & $100.95^{\mathrm{c}}$ & $101.03^{\mathrm{d}}$ & $8.62^{\mathrm{c}}$ & $8.77^{\mathrm{c}}$ & $86.81^{\mathrm{c}}$ & $86.81^{\mathrm{c}}$ & $23.54^{\mathrm{b}}$ & $23.66^{\mathrm{a}}$ \\
\hline 3 & Fennel oil & $88.46^{\mathrm{c}}$ & $88.90^{\mathrm{c}}$ & $107.66^{\mathrm{b}}$ & $107.72^{c}$ & $8.86^{\mathrm{c}}$ & $8.87^{\mathrm{bc}}$ & $87.66^{c}$ & $88.00^{\mathrm{c}}$ & $21.98^{\mathrm{d}}$ & $21.98^{c}$ \\
\hline 4 & Caraway oil & $87.90^{\mathrm{c}}$ & $88.13^{\text {cd }}$ & $104.66^{\mathrm{b}}$ & $104.73^{c}$ & $9.84^{\mathrm{bc}}$ & $9.84^{\mathrm{bc}}$ & $77.33^{\mathrm{d}}$ & $85.80^{\mathrm{c}}$ & $21.96^{\text {de }}$ & $21.96^{c}$ \\
\hline 5 & Basil oil & $122.06^{\mathrm{b}}$ & $122.29^{b}$ & $113.00^{\mathrm{a}}$ & $113.00^{\mathrm{b}}$ & $11.71^{\mathrm{a}}$ & $12.05^{\mathrm{a}}$ & $94.67^{b}$ & $94.67^{\mathrm{b}}$ & $21.94^{\mathrm{de}}$ & $21.94^{c}$ \\
\hline 6 & Thyme oil & $131.66^{\mathrm{a}}$ & $131.60^{\mathrm{a}}$ & $115.66^{\mathrm{a}}$ & $116.24^{\mathrm{a}}$ & $12.09^{\mathrm{a}}$ & $12.14^{\mathrm{a}}$ & $102.33^{\mathrm{a}}$ & $103.33^{\mathrm{a}}$ & $21.86^{\mathrm{e}}$ & $20.03^{\mathrm{d}}$ \\
\hline 7 & Sage oil & $87.90^{\mathrm{c}}$ & $84.74^{\text {de }}$ & $104.33^{b c}$ & $104.59^{\mathrm{c}}$ & $10.38^{\mathrm{b}}$ & $10.38^{\mathrm{b}}$ & $82.33^{\mathrm{cd}}$ & $86.69^{\mathrm{c}}$ & $22.79^{c}$ & $22.79^{\mathrm{bc}}$ \\
\hline
\end{tabular}

Means followed by the same letter (s) within each column do not significantly differ using Duncan's multiple range test at the level of $5 \%$

T

Phytochemicals of sprouts treated with essential oils after 15 days of cold storage at $4{ }^{\circ} \mathrm{C}$

\begin{tabular}{|c|c|c|c|c|c|c|c|c|c|c|c|}
\hline & \multirow[t]{2}{*}{ Treatment } & \multicolumn{2}{|c|}{$\begin{array}{c}\text { Total phenolic } \\
\text { acid } \\
\text { [mg/100 g F.W.] }\end{array}$} & \multicolumn{2}{|c|}{$\begin{array}{l}\text { Total flavonoids } \\
{[\mathrm{mg} / 100 \mathrm{~g} \mathrm{~F} . \mathrm{W} .]}\end{array}$} & \multicolumn{2}{|c|}{$\begin{array}{c}\text { Anthocyanin } \\
\text { [mg/100 g F.W. }]\end{array}$} & \multicolumn{2}{|c|}{$\begin{array}{c}\text { Ascorbic acid } \\
{[\mathrm{mg} / 100 \text { g F.W. }]}\end{array}$} & \multicolumn{2}{|c|}{$\begin{array}{c}\text { DPPH } \\
{[\mathrm{Mmol} \mathrm{TE} / \mathrm{g}} \\
\text { F.W.] }\end{array}$} \\
\hline & & 2012 & 2013 & 2012 & 2013 & 2012 & 2013 & 2012 & 2013 & 2012 & 2013 \\
\hline 1 & Water (control) & $60.33^{\mathrm{d}}$ & $59.81^{\mathrm{e}}$ & $39.19^{d}$ & $40.28^{\mathrm{e}}$ & $5.34^{\mathrm{d}}$ & $5.87^{d}$ & $43.75^{\mathrm{e}}$ & $46.28^{d}$ & $28.06^{\mathrm{a}}$ & $27.85^{\mathrm{a}}$ \\
\hline 2 & Hot water & $87.27^{\mathrm{c}}$ & $86.45^{\mathrm{c}}$ & $98.59^{c}$ & $99.23^{\mathrm{d}}$ & $7.92^{\mathrm{c}}$ & $8.07^{\mathrm{c}}$ & $82.08^{c}$ & $82.51^{\mathrm{c}}$ & $24.15^{\mathrm{b}}$ & $24.86^{\mathrm{a}}$ \\
\hline 3 & Fennel oil & $86.54^{\mathrm{c}}$ & $87.19^{c}$ & $105.76^{\mathrm{b}}$ & $105.17^{\mathrm{c}}$ & $8.16^{\mathrm{c}}$ & $8.17^{\mathrm{bc}}$ & $85.16^{\mathrm{c}}$ & $86.00^{\mathrm{c}}$ & $22.08^{\mathrm{d}}$ & $22.00^{c}$ \\
\hline 4 & Caraway oil & $85.23^{\mathrm{c}}$ & $86.11^{\mathrm{cd}}$ & $102.96^{\mathrm{b}}$ & $102.57^{\mathrm{c}}$ & $9.04^{\mathrm{bc}}$ & $9.24^{b c}$ & $76.83^{d}$ & $81.90^{\mathrm{c}}$ & $21.98^{\mathrm{de}}$ & $22.00^{\mathrm{c}}$ \\
\hline 5 & Basil oil & $120.86^{\mathrm{b}}$ & $119.99^{b}$ & $110.60^{\mathrm{a}}$ & $111.00^{\mathrm{b}}$ & $11.21^{\mathrm{a}}$ & $11.75^{\mathrm{a}}$ & $92.66^{\mathrm{b}}$ & $92.16^{\mathrm{b}}$ & $22.03^{\mathrm{de}}$ & $21.99^{\mathrm{c}}$ \\
\hline 6 & Thyme oil & $130.33^{\mathrm{a}}$ & $130.50^{\mathrm{a}}$ & $113.16^{\mathrm{a}}$ & $114.02^{\mathrm{a}}$ & $11.92^{\mathrm{a}}$ & $12.84^{\mathrm{a}}$ & $101.93^{\mathrm{a}}$ & $102.81^{\mathrm{a}}$ & $21.96^{\mathrm{e}}$ & $20.33^{d}$ \\
\hline 7 & Sage oil & $86.05^{\mathrm{c}}$ & $84.48^{\mathrm{de}}$ & $100.33^{\mathrm{bc}}$ & $102.25^{\mathrm{c}}$ & $10.08^{b}$ & $10.03^{b}$ & $82.00^{\mathrm{cd}}$ & $86.06^{\mathrm{c}}$ & $22.94^{\mathrm{c}}$ & $22.29^{\mathrm{bc}}$ \\
\hline
\end{tabular}

Means followed by the same letter (s) within each column do not significantly differ using Duncan's multiple range test at the level of $5 \%$ 
capacity, in both the seasons (Table 2). The thyme oil treatment produced significant increases in total phenolic content, total flavonoid content, anthocyanin content and ascorbic acid. Thyme and basil oils decreased significantly the DPPH radical scavenging capacity. Accordingly, this treatment (thyme oil) has been chosen to study the storage behaviour, in addition to control treatment. After 15 days of cold storage, all treatments had significant effects on all phytochemical characters compared to the control, in the two seasons (Table 3). The control decreased than the initial time (0 time, Table 2 ) in all studied traits. Thyme oil treatment gave the best results. So, it was chosen to compare with the control during storage.

\section{Antioxidant activity during cold storage}

3.1. Total phenolic content and DPPH radical scavenging capacity

A gradual increase in the total phenolic content reached a maximum value at day 5 and 10 (132.67 and $135.04 \mathrm{mg} \mathrm{GAE} / 100 \mathrm{~g} \mathrm{~F}$.W.) compared to the initial value but this concentration decreased to $129.03 \mathrm{mg}$ at day 15 because of the application of thyme oil
(Figure 2). Keeping in view that the control treatment decreased to $73.84 \mathrm{GAE} / 100 \mathrm{~g} \mathrm{~F}$.W. at day 5 .

On the 15 days-old sprout from storage, the DPPH radical scavenging capacity in the control was reduced to $28.57 \%$ when compared to thyme oil treatment (1.98\%). The DPPH radical scavenging capacity in control increased significantly until day $10(29.43 \mathrm{mg} / 100 \mathrm{~g} \mathrm{~F} . \mathrm{W}$.) and finally decreased $(28.46 \mathrm{mg} / 100 \mathrm{~g} \mathrm{~F} . \mathrm{W}$.) at day 15 , the loss increased to $20.28 \%$ compared with the initial value (Figure $3)$. However, some authors confirm that low storage temperature causes an accumulation of total polyphenols (Policegoudra \& Aradya 2007).

\subsection{Total flavonoid contents}

Total flavonoid content (Figure 4) was found in a higher concentration in 3-day-old sprouts of thyme oil treatment, with values of $115.95 \mathrm{mg} / 100 \mathrm{~g}$ F.W.; after 5 and 10 days of storage, it slightly decreased to $0.021 \%$ and $0.086 \%$, respectively, when compared with the initial value and, finally, reduced by $1.39 \%$. The high loss of flavonoids reached to $10.59 \%$ and $47.89 \%$, after 5 and 10 days, respective$1 \mathrm{y}$, and at 15 days, the loss increased to $58.33 \%$ for the control treatment (average two seasons).

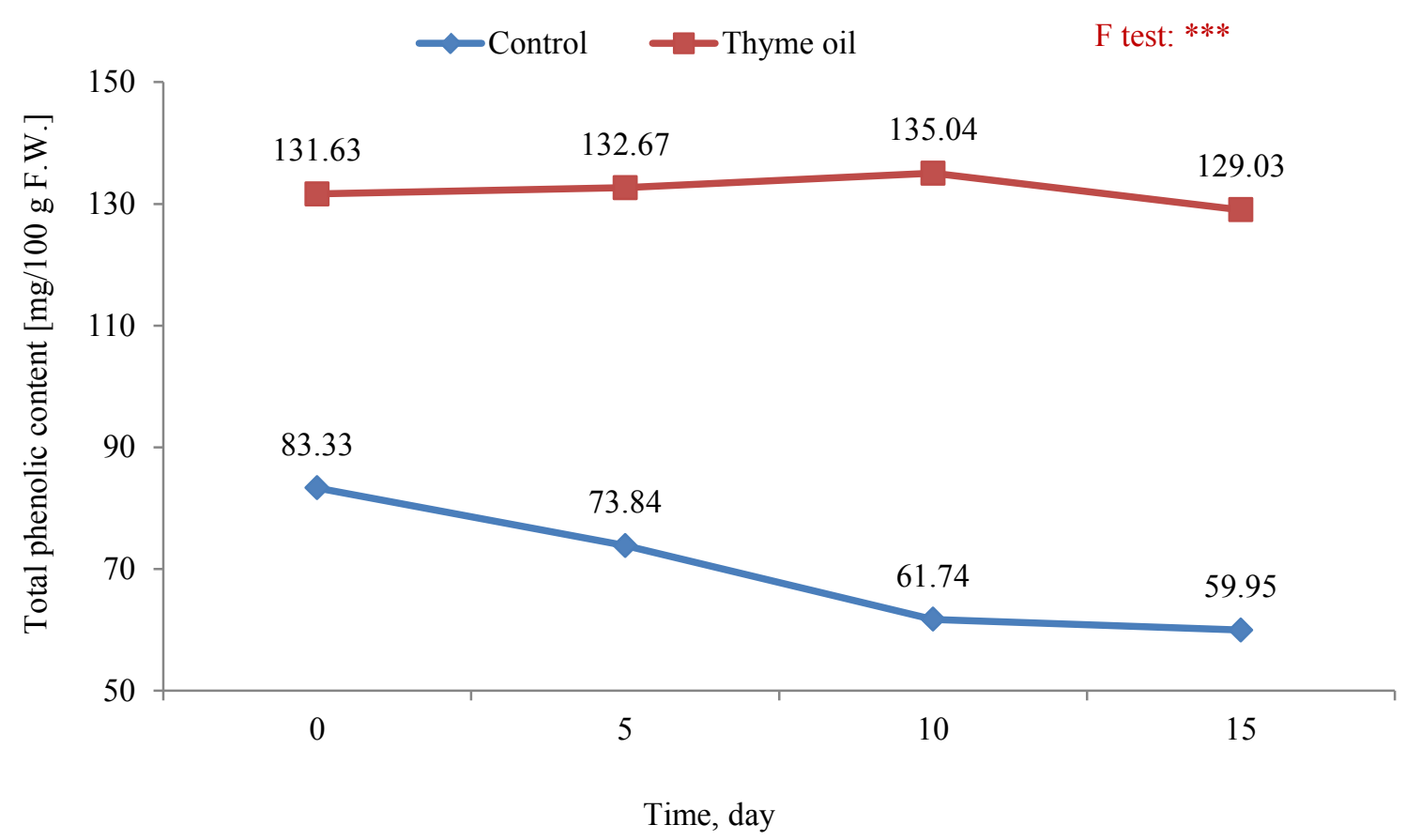

Figure 2. Total phenolic content as affected by the thyme oil compared to control treatment at different storage period 


\subsection{Ascorbic acid}

Thyme oil application slightly decreased vitamin C content $(0.37 \%$ loss $)$ when compared with the initial value after 5 days of storage; the respective losses at the end of cold storage were $1.93 \%$. At day 5 of storage, the vitamin $\mathrm{C}$ content in control treatment was decreased by $37.71 \%$. Finally, the losses reached to $36.25 \%$ (average two seasons, Figure 5).
This behaviour was clearly in contrast to that found for phenolic compounds and glucosinolates.

\subsection{Total chlorophyll}

Changes in chlorophyll amount of broccoli sprouts are illustrated in Figure 6. During the 15 days of storage, no significant change was observed in broccoli sprouts in samples treated with thyme oil compared to the control.

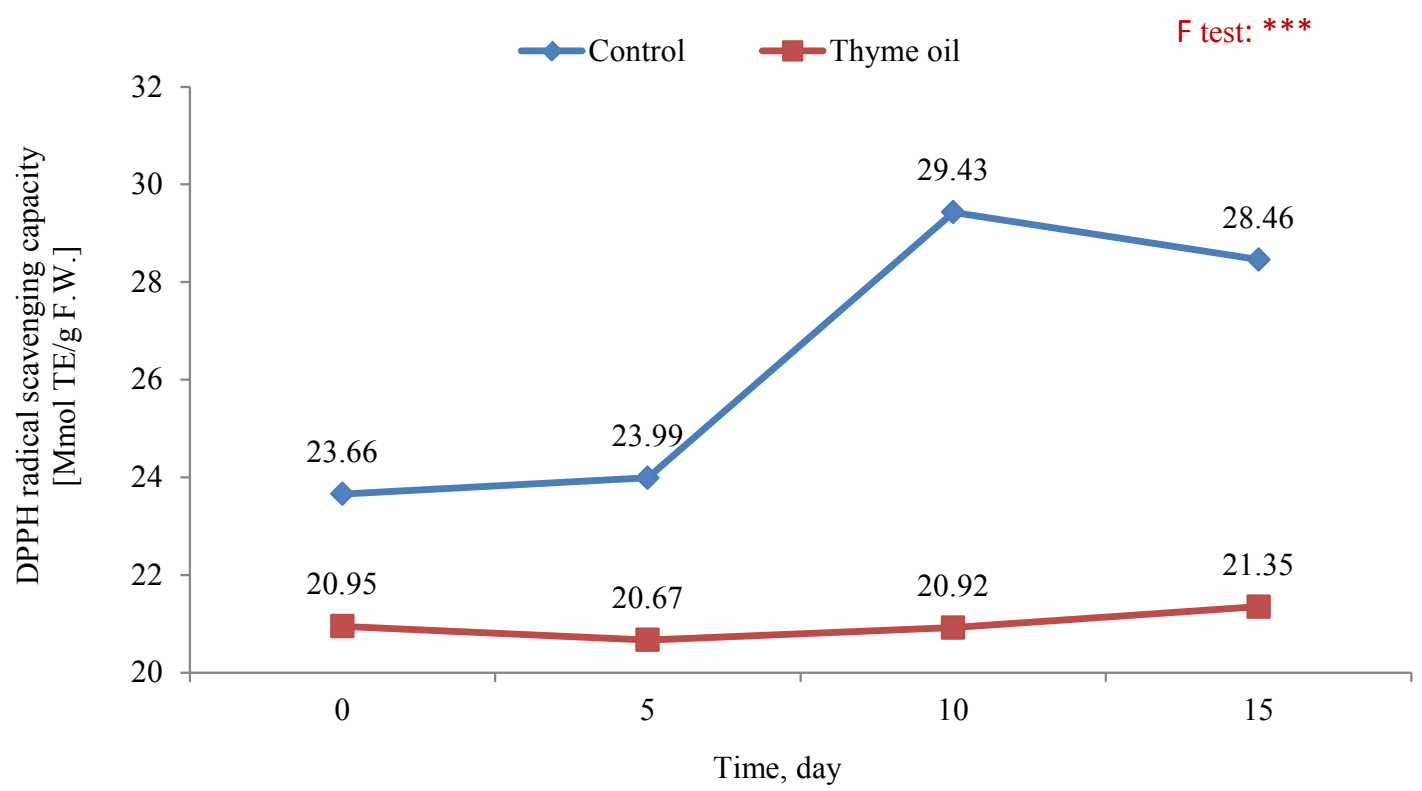

Figure 3. DPPH radical scavenging capacity as affected by the thyme oil treatment compared to the control treatment at different storage period

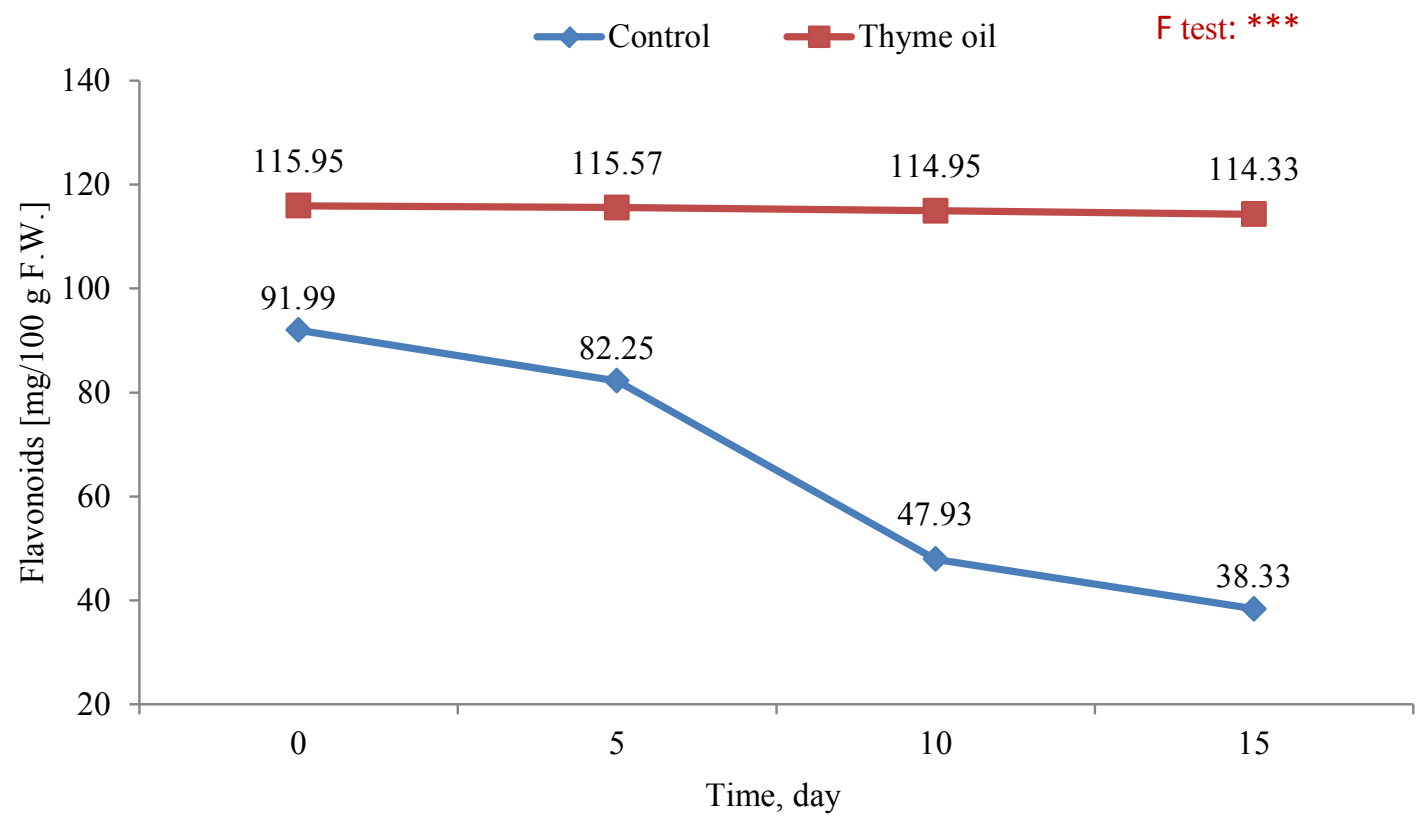

Figure 4. Total flavonoids content as affected by the thyme oil compared to the control treatment at different storage period 


\subsection{Total anthocyanin}

Thyme oil treatment in 3-day-old sprout broccoli increased the level of anthocyanin compared with the control. A slight decrease in anthocyanin content was observed $(2.95 \%)$ at the end of storage periods, compared with the initial value. A gradual decrease was noticed in control treatment and the changes reached about $22.019 \%$ at the end of storage period (average two seasons, Figure 7).

\subsection{Glucosinolates content}

The results of the samples analysed showed significant differences with respect to storage time. Thyme oil application increased glucosinolates content in 3-day-old sprouts compared to control treatments (Figure 8). Thyme oil had a high value of glucosinolates $(27.02 \mu \mathrm{g} / \mathrm{g} \mathrm{F}$.W. $)$, and it slightly decreased up to a concentration of $26.43 \mu \mathrm{g} / \mathrm{g} \mathrm{F}$.W. on day 15 . The change percentage decreased to about
$2.18 \%$ at the end of storage. The reduction in total glucosinolate content was observed in control treatment, in which the change percentage reached about $49.12 \%$ at the end of storage.

\subsection{Microbial population in the stored broccoli sprouts}

The microbial populations were presented in terms of bacterial (total and coliform), fungal and yeast counts (Table 4).

Marked variations were detected amongst the different essential oil treatments from one side and the different microbial groups in the other side. Regarding bacteria, it recorded the highest numbers amongst the groups, along the storage period; fortunately, the coliform bacterial count was not detected at all, indicating the suitability of such preparation for the nutritional aspects. Coliform bacteria are described and grouped based on their common origin or characteristics, as either total or faecal coliform.

$\mathrm{T}$ a $\mathrm{b} 1$ e 4

Count (C.F.U.) of microbial groups on the sprouts of broccoli as a function of cold storage

\begin{tabular}{|c|c|c|c|c|c|}
\hline Microbial group & Treatment & 0 day & 5 days & 10 days & 15 days \\
\hline \multirow{7}{*}{ Bacteria* } & Water (control) & 110 & 8,000 & 19,700 & 200,500 \\
\hline & Hot water & 100 & 10,000 & 18,850 & 21,800 \\
\hline & Fennel oil & 0 & 330 & 6,530 & 15,670 \\
\hline & Caraway oil & 0 & 670 & 3,670 & 4,670 \\
\hline & Basil oil & 0 & 1,650 & 2,760 & 2,950 \\
\hline & Thyme oil & 0 & 500 & 500 & 550 \\
\hline & Sage oil & 20 & 980 & 1,750 & 2,009 \\
\hline \multirow{7}{*}{ Fungi } & Water (control) & 0 & 0 & 10 & 40 \\
\hline & Hot water & 0 & 0 & 0 & 10 \\
\hline & Fennel oil & 0 & 0 & 0 & 0 \\
\hline & Caraway oil & 0 & 0 & 0 & 0 \\
\hline & Basil oil & 0 & 0 & 5 & 10 \\
\hline & Thyme oil & 0 & 0 & 0 & 0 \\
\hline & Sage oil & 0 & 0 & 0 & 0 \\
\hline \multirow{7}{*}{ Yeast } & Water (control) & 0 & 20 & 40 & 50 \\
\hline & Hot water & 0 & 0 & 0 & 10 \\
\hline & Fennel oil & 0 & 0 & 0 & 10 \\
\hline & Caraway oil & 0 & 0 & 0 & 10 \\
\hline & Basil oil & 0 & 0 & 10 & 20 \\
\hline & Thyme oil & 0 & 0 & 0 & 0 \\
\hline & Sage oil & 0 & 0 & 20 & 30 \\
\hline
\end{tabular}

${ }^{*}$ No coliform bacteria were detected; C.F.U. - colony forming unit 
The total group includes faecal coliform bacteria that exist in the intestines of warm-blooded animals and humans and are found in bodily waste, in animal droppings and naturally in soil. Most of the faecal coliform in faecal material (faeces) is known to cause serious human illness. Oppositely, fungi group was the lowest detected groups in the tested treatments. Yeast count came in moderate numbers. However, the numbers of such groups are low enough to indicate the high quality of broccoli sprouts. Thyme oil followed by sage oil recorded the lowest bacterial load. On the other hand, the tested oils except basil oil completely inhibited any fungal growth on broccoli sprouts, along the storage period. Regarding the yeast group, thyme oil was the best. Generally, the microbial load of broccoli sprouts as results of the tested oils was reasonably accepted especially with the absence of any form of coliform bacteria and relatively low microbial load as a whole, representing that there is no any restriction for broccoli sprouts for human consumption.

4. Mature versus sprout broccoli glucosinolate content

The total glucosinolate level in sprout $(27.02 \mu \mathrm{g} / \mathrm{g}$ F.W.) is higher than that in florets $(7.37 \mu \mathrm{g} / \mathrm{g}$ F.W.
(Figures 9 and 10). Glucoraphanin is the most abundant aliphatic glucosinolate present in sprout and reached the highest $(16.24 \mu \mathrm{g} / \mathrm{g} \mathrm{F}$.W.) followed by glucoerucin $(5.9 \mu \mathrm{g} / \mathrm{g} \mathrm{F}$.W. $)$ and glucoiberm $(1.2 \mu \mathrm{g} / \mathrm{g}$ F.W.). However, the florets contain the highest level of aromatic/indolylglucosinolates and neoglucobrassicin $(2.11 \mu \mathrm{g} / \mathrm{g}$ F.W. $)$ followed by glucobrassicin $(1.67 \mu \mathrm{g} / \mathrm{g}$ F.W.). Our results are in agreement with those obtained by Fahey et al. 1997.

\section{DISCUSSION}

The essential oils are frequently known to induce stimulatory or inhibitory effects on the germination of seeds and other physiological processes depending on their basic component, concentration, allelochemicals interaction and selectivity due to the site of application and plant species. The lower doses of essential oil showed a stimulatory activity (Leth 2002).

The obtained results of current study revealed that the used essential oils improved the germination of broccoli seeds. However, thyme oil gave $100 \%$ of sprouts after germination (Table 1). The

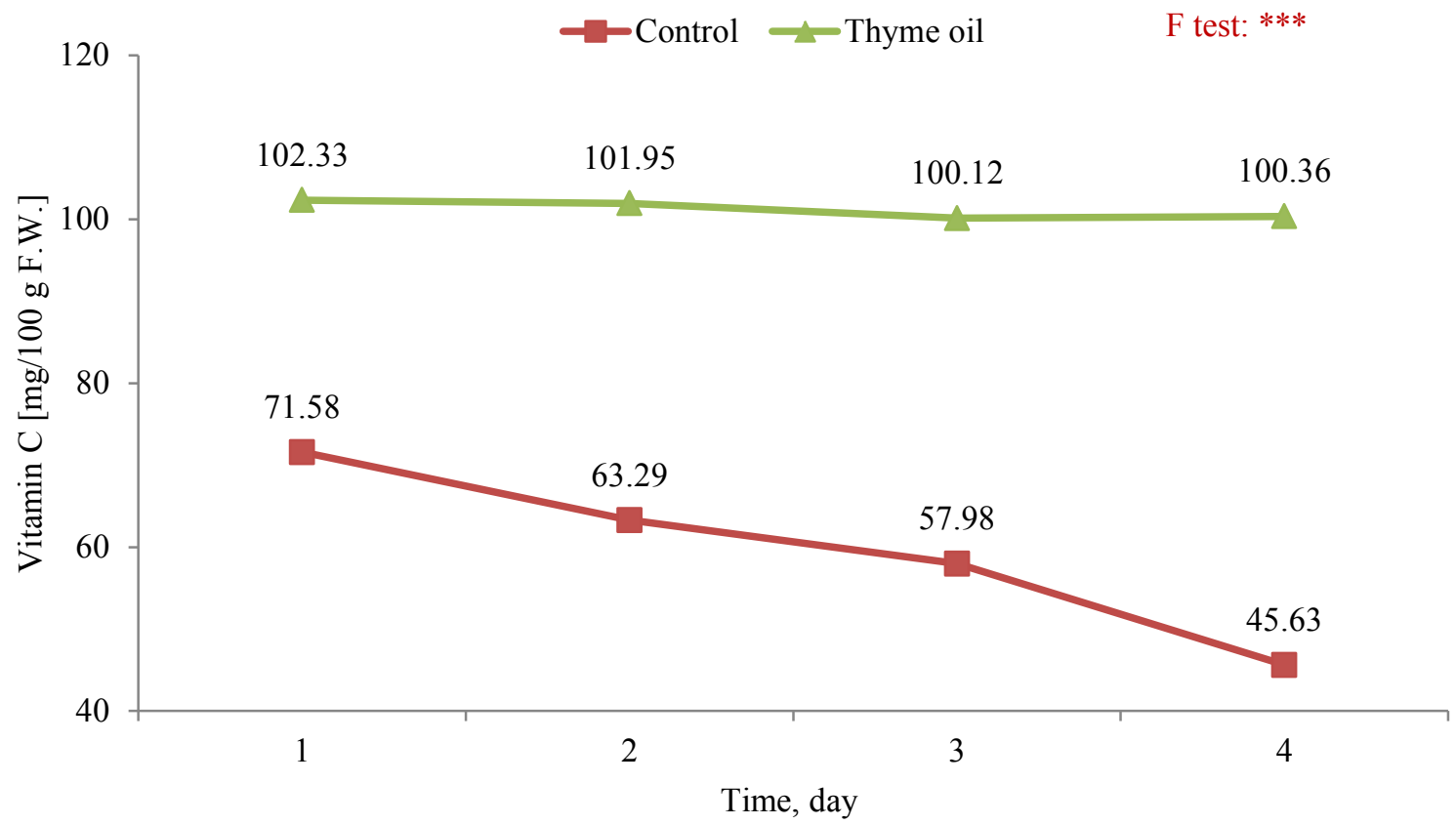

Figure 5.Vitamin C content as affected by the thyme oil compared to the control treatment at different storage period 


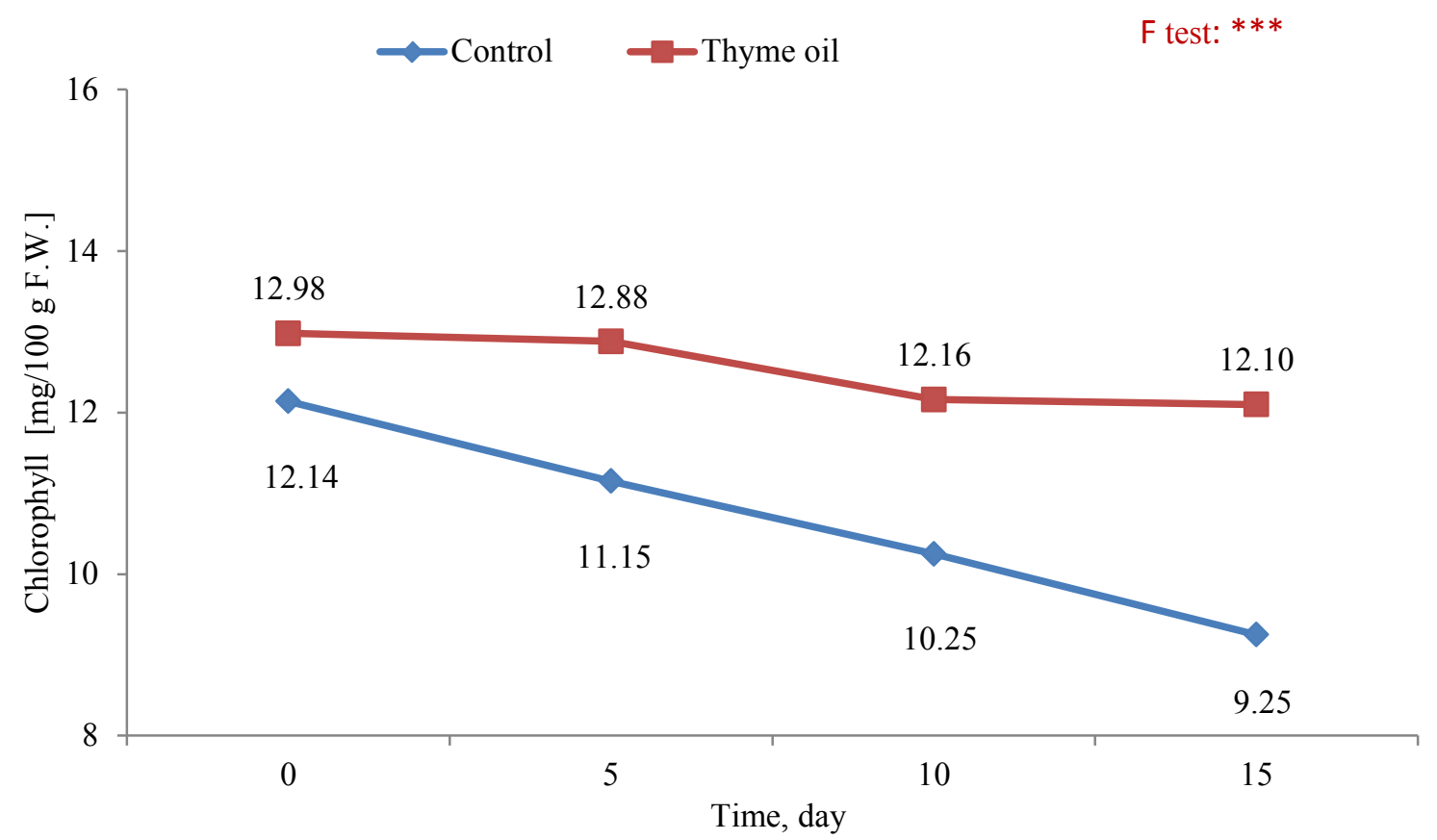

Figure 6. Total chlorophyll content as affected by the thyme oil compared to the control treatment at different storage period

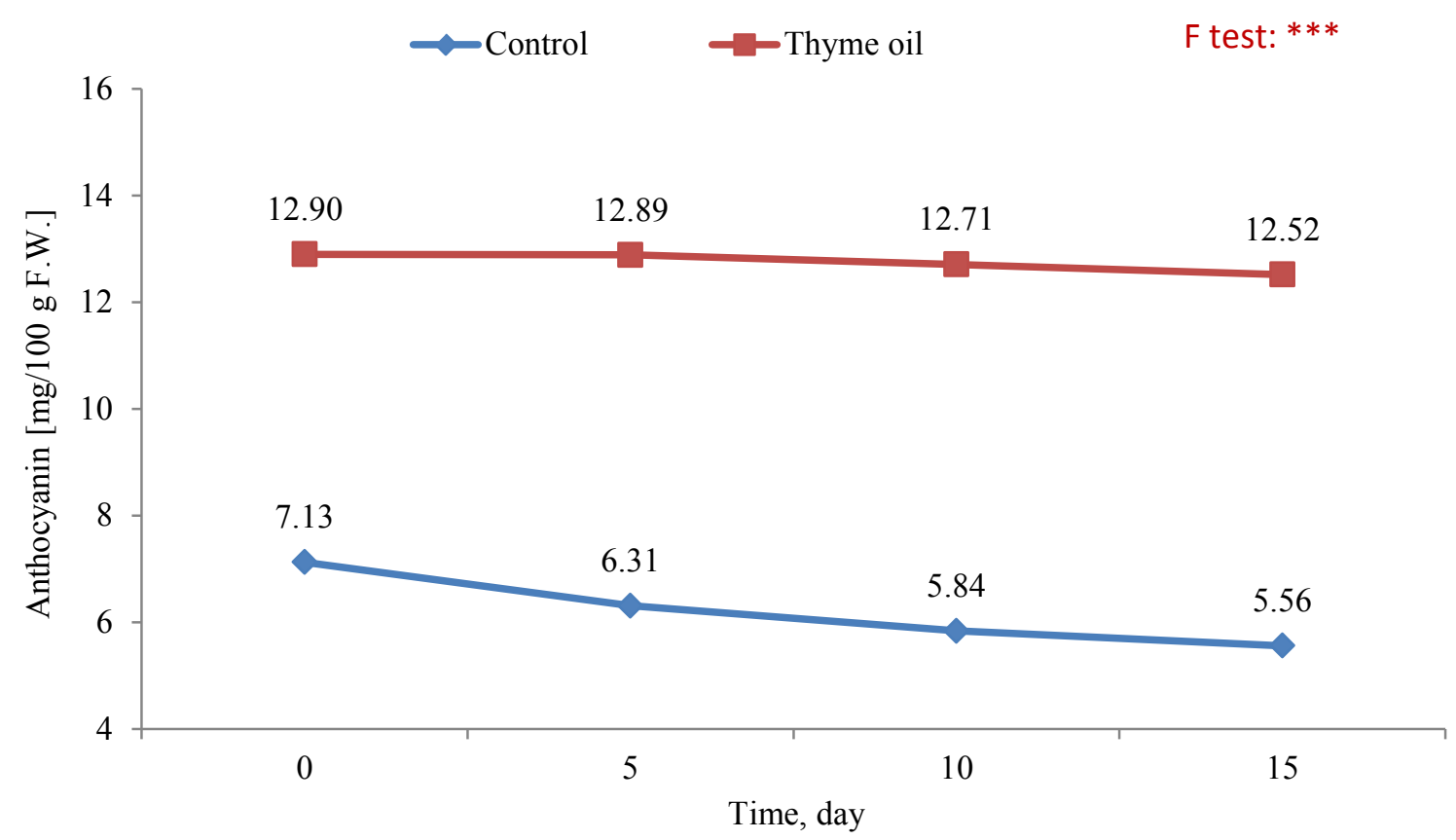

Figure 7. Total anthocyanin content as affected by the thyme oil compared to the control treatment at different storage period 
impact of essential oils on seed germination of other plant species was reported as 24 out of 47 tested terpenoids enhanced the seed germination of $\mathrm{Lac}$ tuca sativa (Vokou et al. 2003). Also, the positive impact of thyme oil on broccoli seeds could be due to its active ingredients. Kulisic et al. (2004) found that the phenolic compound containing thymol and carvacrol as major components exhibited strong antioxidant activity. The essential oils play an important role in the reduction of time need for broccoli germination, where it gives full germination on 3 days compared to normal conditions (7 days). So, we can produce two growing and production cycle in 7 days.

The thyme oil treatment had significant increases in total phenolic content, total flavonoid content, anthocyanin content and ascorbic acid (Table 2). The majority of the antioxidant activity attributes to phenolic compounds, flavonoids and ascorbic acid in essential oils (Heim et al. 2002). Moreover, the antioxidant effect was due to the presence of hydroxyl groups in their chemical structure. Milos et al. (2000) found that the oregano essential oil inhibited hydroperoxide formation and that the $\mathrm{CHO}$ fraction showed the highest antioxidative activity.

The thyme oil showed very poor radical scavenging capacity (Table 2). All other antioxidants showed high and almost the same DPPH radical scavenging capacity effect. It was described that radical scavenging abilities of some compounds can be influenced by their different kinetic behaviour (Kulisic et al. 2004). For slow-reacting compounds, the influence was attributed to the complex reacting mechanism. In our study, probably, the constituents from thyme essential oil involved one or more secondary reactions, which result in the slower reduction of DPPH solutions (Kulisic et al. 2004). After 15 days of storage (Table 3), application of thyme oil may help in the maintenance of the stored sprouts reserves, keeping the internal biochemical enzymatic activities in minimum level and in more stable case, thereby prolonged their shelf life. Also, this treatment was highly effective in the protection of sprouts against the known degradable effects of higher free radicals during storage conditions.

Application of $4 \%$ thyme and basil oils reduced the pathogenic fungi from seed to seedling (Table

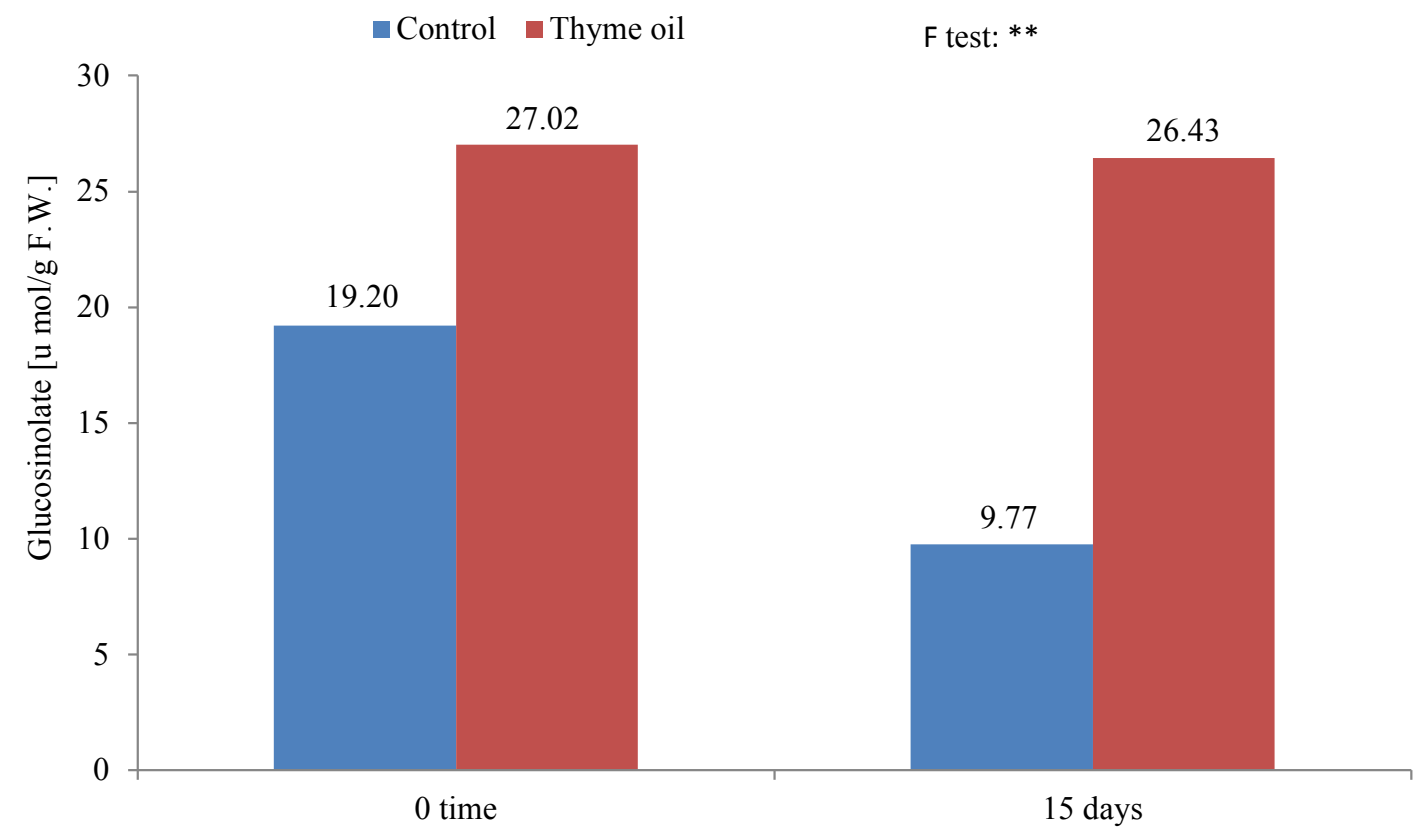

Figure 8. Total glucosinolate content as affected by the thyme oil compared to the control treatment at 0 time and 15 DAS 
4) and had a positive effect on the seed germination of infected seeds, and basic constituents (monoterpenes and antioxidants) tended to slow down the activity of carbohydrates and protein breakdown associated enzymatic systems as well as enzyme involved in respiration and energy metabolism (Nguefack et al. 2005).

Application of thyme oil increases phenolic compound content especially in 10 days compared to that in the initial period of cold storage (Figure 2 ). The results obtained in this study are in agreement with the phenolic profile reported by Pająk et al. (2014). However, some authors confirmed that low storage temperature causes an accumulation of total polyphenols (Villarreal-García et al. 2016).

During cold storage (Figure 3), at day 15 the DPPH in control was reduced to $28.57 \%$ compared to that in sprouts treated with thyme oil $(1.98 \%)$ Nath et al. (2011) observed a steady decrease in the DPPH radical scavenging capacity for $144 \mathrm{~h}$ of storage of broccoli inflorescences. The above behaviour may be due to the constant changes in plant metabolism during storage as a result of oxidative stress, which may include structural changes in synthesis or antioxidant compounds (Xiao et al. 2014).

In our study, thyme oil treatments possibly affected the environmental stresses of sprout broccoli; however, in contrast with control treatment, total flavonoid content decreased to $58.33 \%$ compared to that measured at initial period (Figure 4). An explanation for this could be the very high respiratory rate of broccoli (Izumi et al. 1996) that could increase the metabolism and, therefore, the degradation of the phenolic compounds.

During cold storage, broccoli's potential for maintaining the stability of vitamin $\mathrm{C}$ levels found in the fresh product was due to thyme oil application (Figure 5). Thus, according to previous report (Davey et al. 2000), broccoli retain its vitamin C levels because of the protection of other oxygen scavengers.

Total chlorophyll and total anthocyanin contents slightly decreased at $4^{\circ} \mathrm{C}$ because thyme oil application prevented the degradation of anthocyanin and chlorophyll (Figures 6 and 7), but this might be lost at the control, which may be associated with water loss (Haminiuk et al. 2012; Sabir 2012).

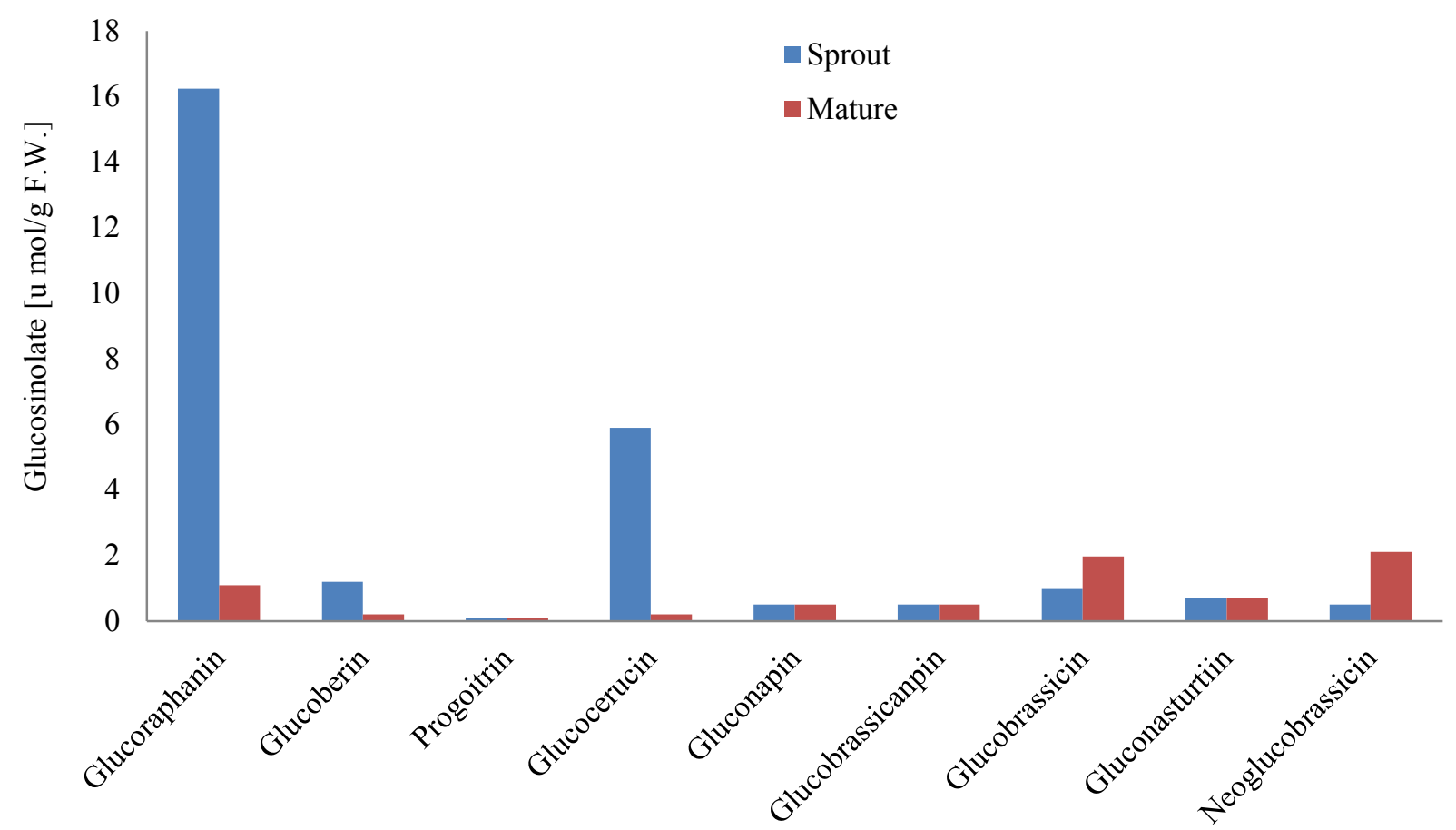

Figure 9. Total and individual levels of aliphatic, aromatic and indole glucosinolates in 3-day-old broccoli sprout and mature at harvest 

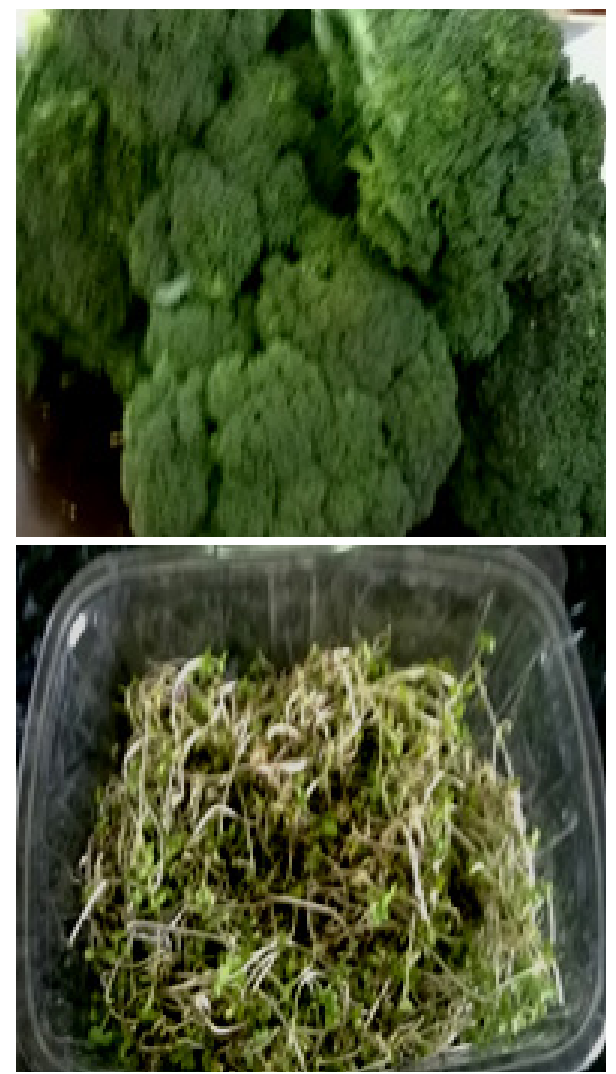

Figure 10.(a) Mature plant and (b) sprout of broccoli

Thyme oil increased glucosinolates content in 3-day-old sprouts, compared to control treatments (Figure 8). The highest decrease in total glucosinolate content was observed in control treatment at the end of storage. This behaviour is consistent with experiments conducted by Howard et al. (1997), who reported a decrease of $50 \%$ on day 14 of storage at $4^{\circ} \mathrm{C}$ in broccoli sprouts. Cultural practices, handling and storage conditions, as well as the vegetable preparation, have a potential impact on the glucosinolates content, causing a change in the rate of formation of sulphoraphane (Jeffery \& Araya 2009). However, the total glucosinolate content of the seedling was highest at both 4 and 7 days. Glucosinolates are plant defence compounds and, consistent with this function, are accumulated preferentially in the organs that contribute most to plant fitness at a particular moment in the growth cycle (Halkier \& Gershenzon 2006).

The total glucosinolate content in sprout is higher than that in florets (Figures 9 and 10). Glucosinolates are divided into three major categories: ali- phatic, indole and aromatic glucosinolates (Yan \& Chen 2007). The high content of the aliphatic glucosinolates in broccoli sprouts is mainly attributed to glucoraphanin (16.24 $\mu \mathrm{g} / \mathrm{g}$ F.W.). The glucoraphanin can be hydrolysed to form sulphoraphane. This compound plays an important role in controlling, preventing or blocking any of the multiple stages of the carcinogenic process (Parnaud et al. 2004). The florets contain the highest level of aromatic/indolylglucosinolates and neoglucobrassicin $(2.11 \mu \mathrm{g} / \mathrm{g}$ F.W.) followed by glucobrassicin (1.67). Indole-3-carbinol $\left(\mathrm{C}_{9} \mathrm{H}_{9} \mathrm{NO}\right)$ is produced by the breakdown of the glucobrassicin. Indole-3-carbinol is a powerful strategy for achieving protection against carcinogenesis, mutagenesis and other forms of toxicity.

The impact of harvest and storage techniques on phytochemical has only recently begun to be explored. In general, phenolic compounds are considered to be relatively stable at cool temperature storage.

\section{CONCLUSIONS}

The results of this study show that the content of phytochemicals such as phenolic compounds, total flavonoids, anthocyanin, chlorophyll, ascorbic acid and glucosinolate in broccoli sprouts is stable during storage after 15 days at $4^{\circ} \mathrm{C}$ because of the application of essential oils. Thyme oil gave the best results on the content of phytochemicals and had a highest content of the glucosinolate and reduced the microbial load compared to the control. Fortunately, the coliform bacteria was not detected in all treatments. The results also indicate that the total glucosinolate content in sprout is higher than that in florets. The sprouts had significant values of glucoraphanin that can be hydrolysed to sulphoraphane. This compound plays an important role in controlling, preventing or blocking any of the multiple stages of the carcinogenic process. Therefore, the consumption of this food can play an important role in the prevention of related diseases with free radical generation, considering broccoli sprouts as a functional food. 


\section{REFERENCES}

AOAC. 2000. No. 967.21 Ascorbic acid in vitamin preparation and juices. In Official Method of Analysis, $17^{\text {th }}$ ed. Gaithersburg, MD: Association of Official Analytical Chemists.

BAENAS, N. - GARCÍA-VIGUERA, C. - MORENO, D.A. 2014. Biotic elicitors effectively increase the glucosinolates content in brassicaceae sprouts. In Journal of Agricultural and Food Chemistry, vol. 62, pp. 1881-1889. DOI: 10.1021/jf404876z

BRAND-WILLIAMS, W. - CUVELIER, M.E. - BERSET, C. 1995. Use of a free radical method to evaluate antioxidant activity. In Lebensmittel-Wissenschaft \& Technologie, vol. 28, pp. 25-30.

CAMPAS-BAYPOLI, O.N. - SÁNCHEZ-MACHADO, D.I. - BUENO-SOLANO, C. - RAMRÍEZ-WONG, B. - LÓPEZ-CERVANTES, J. 2010. HPLC method validation for measurement of sulforaphane level in broccoli by-products. In Biomedical Chromotography, vol. 24, pp. 387-392. DOI: 10.1002/bmc.1303

CHARLES, D.J. - SIMON, J.E. 1990. Comparison of extraction methods for the rapid determination of essential oil content and composition of basil. In Journal of the American Society for Horticultural Science, vol. 3 , pp. 458-462.

COLLINS, C.H. - LYNE, I. 1985. Microbiological methods. $5^{\text {th }}$ ed. London, UK: Butterworth-Heinemann, London, pp. 167-181.

DAVEY, M.W. - VAN MONTAGU, M. - INZE', D. SANMART'IN, M. - KANELLIS, A. - SMIRNOFF, N. - BENZIE, I.J.J. - STRAIN, J.J. - FAVELL, D. FLETCHER, J. 2000. Plant L-ascorbic acid: chemistry, function, metabolism, bioavailability and effects of processing. In Journal of the Science Food and Agriculture, vol. 80 , pp. 825-860.DOI: 10.1002/(SICI )1097-0010(20000515)80:7<825::AID-JSFA598>3.0. $\mathrm{CO} ; 2-6$

DU, G.M. - MA, F. - LIANG, D. 2009. Antioxidant capacity and the relationship with polyphenol and vitamin $\mathrm{C}$ in actinidia fruits. In Food Chemistry, vol. 113, pp. 557-562. DOI: 10.1016/j.foodchem.2008.08.025

FAHEY, J.W. - ZHANG, Y. - TALALAY, P. 1997. Broccoli sprouts: An exceptionally rich source of inducers of enzymes that protect against chemical carcinogens. In Proceedings National Academy of Sciences of the United States of America, USA, vol. 94, pp. 10367-10372.

FISKAA, S.H. - IREN, G.B. - ASBJORN, K. - BENGTSSON, G. 2009. Effect of cold storage and harvest date on bioactive compounds in curly kale (Brassica oleracea L. var. acephala). In Postharvest Biology and Technology, vol. 51, pp. 36-42. DOI: 10.1016/j.postharvbio.2008.04.001

HALKIER, B.A. - GERSHENZON, J. 2006. Biology and biochemistry of glucosinolates. In Annual Review of Plant Biology, vol. 57, pp. 303-333. DOI: 10.1146/ annurev.arplant.57.032905.105228

HAMINIUK, C.W.I. - MACIEL, G.M. - PLATA-OVIEDO, M.S.V. - PERALTA, R.M. Phenolic compounds in fruits - an overview. In International Journal Food
+ Science Technology, vol. 47, no. 10, pp. 2023-2044. DOI: $10.1111 / \mathrm{j} .1365-2621.2012 .03067 . \mathrm{x}$

HEIM, K.E. - TAGLIAFERRO, A.R. - BOBILYA, D.J. 2002. Flavonoid antioxidants: chemistry, metabolism and structure-activity relationships. In The Journal of Nutritional Biochemistry, vol. 13, pp. 572-584. DOI: http://dx.doi.org/10.1016/S0955-2863(02)00208-5

HOWARD, L.A. - JEFFERY, E.H. - WALLING M.A. KLEIN, B.P. 1997. Retention of phytochemicals in fresh and processed broccoli. In Journal of Food Science, vol. 62, pp. 1098-1104. DOI: 10.1111/j.13652621.1997.tb12221.x

ISTA (INTERNATIONAL SEED TESTING ASSOCIATION). 2010. International rules for seed testing. ISTA News Bulletin, no. 139, 48 pp.

IZUMI, H. - WATADA, A.E. - DOUGLAS, W. 1996. Optimum $\mathrm{O}_{2}$ or $\mathrm{CO}_{2}$ atmosphere for storing broccoli inflorescences at various temperatures. In Journal of the American Society for Horticultural Science, vol. 121, pp. 127-131.

M. ARAYA, M. 2009. Physiological effects of broccoli consumption. In Phytochemistry Reviews, vol. 8, pp. 283-298. DOI: 10.1007/s11101-008-9106-4

JUSTESEN, U. - KNUTHSEN, P. 2001. Composition of flavonoids in fresh herbs and calculation of flavonoid intake by use of herbs in traditional Danish dishes. In Food Chemistry, vol. 73, pp. 245-250.

KIDDLE, G.A. - BENNETT, R.N. - BOTTING, N.P. DAVIDSON, N.E. - ROBERTSON, A.A.B. - WALLSGROVE, R.M. 2001. High performance liquid chromatography separation of natural and synthesic desulfoglucosinolates and their chemical validation by spectroscopic, NMR, and CI-MS methods. In Phytochemical Analysis, vol. 12, pp. 226-242. DOI: $10.1002 /$ pca. 589

KONCZAK, I.- ZHANG, W. 2004. Anthocyanins - more than nature's colours. In Journal of Biomedicine Biotechnology, pp. 239-240. DOI: 10.1155S1110724304407013

KULISIC, T. - RADONIC, A. - KATALINIC, V. - MILOS, M. 2004. Use of different methods for testing antioxidative activity of oregano essential oil. In Food Chemistry, vol. 85, pp. 633-640. DOI: $10.1016 /$ j.foodchem.2003.07.024

LETH, V. 2002.Use of essential oils as seed treatment. In IPGRI Newsletter, September, pp. 15-16.

LÓPEZ-CERVANTES, J. - TIRADO-NORIEGA, L.G. SÁNCHEZ-MACHADO, D.I. - CAMPAS-BAYPOLI, O.N. - CANTÚ-SOTO1, E.U. - NÚÑEZ-GASTÉLUM, J.A. 2013. Biochemical composition of broccoli seeds and sprouts at different stages of seedling development. In International Journal of Food Science and Technology, vol. 48, no. 11, pp. 2267-2275. DOI: $10.1111 /$ ijfs. 12213

LORENZ, R.C. - HSU, J.C.- TUOVINEN, O.H. 1982. Performance variability, ranking, and selection analysis of membrane filters for enumerating coliform bacteria in river water. In Journal of the American Water Works Association, pp. 429-437.

MARSHALL, R.T. 1992. Standard methods for the examination of dairy products. In American Public 
Health Association, Washington, D.C. USA. ISBN10: 0875530028

MATUSHESKI, N.V. - JUVIK, J.A. - JEFFERY, E.H. 2004. Heating decreases epithiospecifier protein activity and increases sulforaphane formation in broccoli. In Phytochemistry, vol. 65, no. 9, pp. 1273-1281. DOI:10.1016/j.phytochem.2004.04.013

MILOS, M. - MASTELI, J.- JERKOVIC, I. - KATALINIC, V. 2000. Chemical composition and antioxidant activity of the essential oil of oregano (Origanum vulgare L.) grown wild in Croatia. In Rivista Italiana EPPOS, Gennaio, pp. 616-624.

NATH, A. - BAGCHI, B. - MISRA, L.K. - DEKA, B.C. 2011. Changes in post-harvest phytochemical qualities of broccoli florets during ambient and refrigerated storage. In Food Chemistry, vol. 127, pp. 1510-1514. DOI:10.1016/j.foodchem.2011.02.007

NGUEFACK, J. - SOMDA, I. - MORTENSEN, C.N.AMVAM ZOLLO, P.H. 2005. Evaluation of five essential oils from aromatic plants of Cameroon for controlling seed-borne bacteria of rice (Oryza sativa L.) In Seed Science and Technology, vol. 33, pp. 397-407. DOI: http://dx.doi.org/10.15258/sst.2005.33.2.12

PAJĄK, P. - SOCHA, R. - GAŁKOWSKA, D. ROŻNOWSKI J. - FORTUNA, T. 2014. Phenolic profile and antioxidant activity in selected seeds and sprouts. In Food Chemistry, vol. 143, pp. 300-306. DOI:10.1016/j.foodchem.2013.07.064

PARNAUD, G. - LI, P. - CASSAR, G. - ROUIMI, P. TULLIEZ, J. - COMBARET, L. - GAMET-PAYRASTRE, L. 2004. Mechanism of sulforaphane-induced cell cycle arrest and apoptosis in human colon cancer cells. In Nutrition and Cancer, vol. 48, no. 2, pp. 198-206. DOI: 10.1207/s15327914nc4802_10

PÉREZ-BALIBREA, S. - MORENO D.A. - GARCÍAVIGUERA, C. 2011. Genotypic effects on the phytochemical quality of seeds and sprouts from commercial broccoli cultivars. In Food Chemistry, vol. 125, pp. 348-354. DOI:10.1016/j.foodchem.2010.09.004

SABIR, K.F. 2012. Postharvest quality response of broccoli florets to combined application of 1 - methyl cyclopropene and modified atmosphere. In Agricultural and Food Science, vol. 21, no. 4, pp. 421-429.
SNEDECOR, G.W. - COCHRAN, W.G. 1989. Statistical Methods, $8^{\text {th }}$ ed. $2^{\text {nd }}$ Printing. In Lowa State Universty Press, Ames, Lowa, 50014, USA. ISBN 0-8138-1516-4 VALLEJO, F. - TOMA'S-BARBERA'N, F.A. - GARC'IAVIGUERA, C. 2002. Glucosinolates and vitamin C content in edible parts of broccoli inflorescences after domestic cooking. In European Food Research and Technology, vol. 215, pp. 310-316. DOI: 10.1007/ s00217-002-0560-8

VILLARREAL-GARCIA, D. - NAIR, V. - GISNEROS -ZEVALLOS, L. - JACOBO-VEAZQUEZ, D.A. 2016. Plants as biofacttories: Postharvest stress-Induced accumulation of phenolic compounds and glucosinolates in broccoli subjected to wounding stress and exogenous phytohormones. In Fronties in Plant Science, vol. 7, no. 45, pp. 1-11. DOI: 10.3389/ fpls.2016.00045

VOKOU, D. - DOUVLI, P. - BLIONIS, G.J. - HALLEY, J.M. 2003. Effects of monoterpenoids, acting alone or in pairs, on seed germination and subsequent seedling growth. In Journal of Chemical Ecology, vol. 29, pp. 2281-2301. DOI: 10.1023/A:1026274430898

WEST, L.G. - MEYER, K.A. - BALCH, B.A - ROSSI, F.J. - SCHULTZ, M.R. - HAAS, G.W. 2004. Glucoraphanin and 4-hydroxyglucobrassicin contents in seeds of 59 cultivars of broccoli, raab, kohlrabi, radish, cauliflower, Brussels sprouts, kale, and cabbage. In Journal of Agriculture and Food Chemistry, vol. 52,pp. 916-926. DOI: 10.1021/jf0307189

XIAO, Z. - LESTER, G.E. - LUO, Y. - XIE, Z. - YU, L. - WANG, Q. 2014. Effect of light exposure on sensorial quality, concentrations of bioactive compounds and antioxidant capacity of radish microgreens during low temperature storage. In Food Chemistry, vol. 151, pp. 472-479. DOI:10.1016/j.foodchem.2013.11.086

YAN, X. - CHEN, S. 2007. Regulation of plant glucosinolate metabolism. In Planta, vol. 226, pp. 1343-1352. DOI: $10.1007 / \mathrm{s} 00425-007-0627-7$

YUAN, G.F. - WANG, X.P. - GUO, R.F. - WANG, Q.M. 2010. Effect of salt stress onphenolic compounds, glucosinolates, myrosinase and antioxidant activity in radish sprouts. In Food Chemistry, vol. 121, pp. 1014-1019. DOI: 10.1016/j.foodchem.2010.01.040

Received: July 2, 2016 